\title{
NEW MIGRAINE PREVENTIVE OPTIONS: AN UPDATE WITH PATHOPHYSIOLOGICAL CONSIDERATIONS
}

\author{
Marcelo E. Bigal, Alan M. Rapoport, Fred D. Sheftell and Stewart J. Tepper
}

RHCFAP/3109

BIGAL ME et al. - New migraine preventive options: an update with pathophysiological considerations. Rev. Hosp. Clín.

Fac. Med. S. Paulo 57(6):293-298, 2002.

BACKGROUND: The pharmacological treatment of migraine may be acute or preventive. Frequent, severe and longlasting migraine attacks require prophylaxis. Multiple threads of research over the last 15 years have led to the concept that migraine is generated from a hyperexcitable brain. A variety of causes for hyperexcitability of the brain in migraine have been suggested. These causes include low cerebral magnesium levels, mitochondrial abnormalities, dysfunctions related to increased nitric oxide or the existence of a P/Q type calcium channelopathy. The better knowledge about migraine pathophisiology led us to discuss new treatment options.

OBJECTIVES: The aim of the present study is to present an evidence-based review of some new drugs or some agents that even though available for a long time, are not frequently used.

METHODS/RESULTS: We present a review of anticonvulsants with various mechanisms of action such as lamotrigine, gabapentin, topiramate, tiagabine, levetiracetam and zonisamide. We also review natural products, like riboflavin and magnesium, botulinum toxin A, a specific CGRP antagonist and the anti-asthma medication montelukast, with pathophysiological discussion.

CONCLUSIONS: We aimed to present an update of newer or less frequently used preventive migraine therapies, drugs that might reduce the burden and the costs of a disease that should be considered as a public health problem all around the world.

DESCRIPTORS: Migraine. Preventive treatment. Prophylactic treatment. Update.

\section{INTRODUCTION}

Multiple threads of research over the last 15 years have led to the concept that migraine is generated from a hyperexcitable brain ${ }^{1}$. In spite of the fact that we are not sure whether migraine is generated in the cortex or brainstem, one possible scenario would include a cascade of events beginning with cortical activation, followed by brainstem activation, leading to activation of ascending and descending pathways, with initiation of a perimeningeal vasodilatation and neurogenic inflammation ${ }^{2-4}$. A variety of causes for hyperexcitability of the brain in migraine have been suggested. These include low cerebral magnesium levels, mitochondrial abnormalities, dysfunctions related to increased nitric oxide or the existence of a P/Q type calcium channelopathy ${ }^{5-8}$.

Effective migraine treatment begins with making an accurate diagnosis, ruling out alternate causes, and ad-

From the New England Center for Headache, Stamfor, CT, U.S. dressing the headache's impact on the patient. The treatment involves nonpharmacologic behavioral and physical measures and pharmacotherapy. The pharmacological treatment of migraine may be acute or preventive, remembering that they are not mutually exclusive. A significant number of patients will benefit from a combined approach.

The aim of the present study is to present an evidence-based review of some new drugs or some agents that even though available for a long time, are not frequently used. 


\section{PREVENTIVE TREATMENT}

Preventive medications are usually taken in a daily basis, to reduce the frequency, duration or severity of attacks. Some good reasons for migraine prevention are: 1 - Frequently recurring migraine that significantly interferes with the patient's daily routine, despite using an appropriate acute treatment; 2 - Failure, contraindication or adverse events when using acute medications; 3 - Overuse of acute medications; 4 - Patient preference.

The major medication groups for preventive migraine treatment include B-adrenergic blockers, antidepressants of all types, calcium channel antagonists, serotonin antagonists and anticonvulsivants. We will focus on new and not frequently used options.

\section{1 - Natural Products}

\section{$A$ - Vitamin B2 (riboflavin)}

A mitochondrial dysfunction resulting in impairment of oxygen metabolism and low cellular energy levels may play a role in migraine pathogenesis ${ }^{7}$. Riboflavin (vitamin B2) is the precursor of flavin mononucleotide and flavin adenine dinucleotide, which are required for the activity of flavoenzymes involved in the electron transport chain in the mitochondria of the cells ${ }^{9}$. Given to patients with mitochondriopathies, riboflavin improved some clinical and biochemical parameters ${ }^{10}$.

A double blind study of large doses of riboflavin (400 mg / day) compared with placebo in migraine prevention showed that riboflavin was significantly superior at reducing the attack frequency, headache intensity and other indexes after three months of therapy. The proportion of patients that improved at least $50 \%$ was $15 \%$ for placebo and $59 \%$ for riboflavin. No serious adverse events were reported ${ }^{11}$.

\section{B - Magnesium}

As mentioned above, low levels of magnesium are probably associated with the cascade of events that might trigger migraine. It seems reasonable that this ion had been studied in the preventive and acute treatments of migraine.

Some studies have demonstrated low intracellular magnesium in the migrainous brain ${ }^{12-13}$. Two studies evaluated the effects of magnesium supplementation in the preventive treatment of migraine, with contradictories results. The first one enrolled 81 patients in a placebo-controlled study. The attack frequency was reduced by $41.6 \%$ in the magnesium group and by $15.8 \%$ in placebo group. Adverse events were diarrhea and gastric irritation ${ }^{14}$. The other study evaluated 69 patients and was discontinued because they were not able to identify benefits in magnesium group. These patients had severe diarrhea and may not have absorbed the magnesium from the gastrointestinal tract ${ }^{15}$.

The studies differed in the amount of magnesium ( 24 vs. $20 \mathrm{mmol}$ ) and in the salt (dicitrate vs. aspartate). These differences may explain at least part of the contradictory conclusions. Despite these conflicting results, many clinicians believe that magnesium can be useful in some patients. It can be tapered from $64 \mathrm{mg}$ bid (Slow-Mag) to $128 \mathrm{mg}$ bid, or be used in higher doses of other salts at a level of $200 \mathrm{mg}$ bid or $400 \mathrm{mg}$ QD.

\section{2 - Antiepileptic Drugs}

\section{C-Gabapentin}

Gabapentin is an anticonvulsant agent structurally related to the inhibitory neurotransmitter Gammaaminobutyric acid (GABA) ${ }^{16}$. Although gabapentin was developed as a structural analog of GABA that would penetrate the blood-brain barrier (unlike GABA) and mimic the action of GABA at inhibitory neuronal synapses, the drug has no direct GABA-mimetic action and its precise mechanism of action has not been elucidated ${ }^{17}$.

Gabapentin seems to be an anticonvulsant particularly effective in treating chronic pain syndromes. A recent double-blind trial that used gabapentin from $1800 \mathrm{mg}$ to $2400 \mathrm{mg}$ per day showed this drug to be superior to placebo in reducing frequency and intensity of pain ${ }^{18}$. Gabapentin was effective in $46 \%$ of patients, against $14 \%$ of placebo that had failed to other therapies. The most common adverse events of this drug are dizziness, drowsiness and weight gain.

\section{D - Topiramate}

Topiramate is a structurally unique anticonvulsant, rapidly and almost completely absorbed. It is eliminated predominantly unchanged in the urine. This drug differs structurally from other currently available anticonvulsant agents ${ }^{19}$. The spectrum of topiramate's anticonvulsant activity resembles that of carbamazepine and phenytoin ${ }^{19}, \mathrm{al}-$ though differences in certain animal models have been observed and additive effects appear to occur when the drug is combined with these anticonvulsants ${ }^{20}$. It has been associated with weigh loss, not weight gain, which is a common reason to discontinue preventive medication. Almost all patients complain about slight peripheral paresthesias in the hands and feet. A rare side effect is cognitive dysfunction, fully reversed with therapy discontinuation.

One study that used topiramate in migraine and chronic daily headache reported one third of the patients with significant improvement, one third with moderate improvement and another third without improvement ${ }^{21}$.

A second double-blind study showed that topiramate produced more than $50 \%$ decrease in pain in $46.7 \%$ of patients vs. $6.7 \%$ of placebo. A third 
double blind study, using a mean topiramate dose of $125 \mathrm{mg}$ (range 25 to $200 \mathrm{mg}$ ) also showed a significant improvement against placebo. Topiramate must be gradually increased from a 15 or $25 \mathrm{mg}$ per day dose in order to avoid side effects ${ }^{22}$.

\section{E-Tiagabine}

Although the precise mechanism of action of tiagabine is unknown, the drug enhances inhibitory neurotransmission mediated by $\mathrm{GABA}^{23}$. Tiagabine increases the amount of GABA available in extracellular spaces of the globus pallidus, ventral pallidum, and substantia nigra suggesting a GABA-mediated anticonvulsant mechanism of action ${ }^{24}$.

Tiagabine is an antiepileptic drug still poorly studied as a preventive migrainous option. An open-label clinical trial with 41 patients, all previously treated with divalproex and discontinued due to lack of efficacy or adverse events, showed that 5 patients had remission and 33 had significant reduction of the frequency of attacks. The mean dose was $10 \mathrm{mg} / \mathrm{day}^{25}$.

\section{$F$ - Levetiracetam}

Levetiracetam, a pyrrolidine derivative, is an anticonvulsant agent that is structurally unrelated to other currently available anticonvulsants ${ }^{26}$. The mechanism of anticonvulsant action of levetiracetam is unknown and does not appear to be related to any known mechanisms involved in excitatory or inhibitory neurotransmission $^{27}$. In animal models, levetiracetam conferred no protection against single seizures induced by electrical current or different chemoconvulsants and offered only limited protection in submaximal stimulation and threshold tests. Protection was observed against secondarily generalized activity from focal seizures induced by two chemoconvulsants known to induce seizures that mimic some features of human complex partial seizures with secondary generalization. Levetiracetam also showed inhibitory properties in the kindling model in rats, another model of human complex partial seizures ${ }^{27}$.

Levetiracetam is not extensively metabolized in humans, with $66 \%$ of an administered dose excreted unchanged in urine. About $24 \%$ of an administered dose is metabolized to an inactive metabolite by enzymatic hydrolysis of the acetamide group, which does not depend on hepatic cytochrome P-450 (CYP) isoenzymes ${ }^{27}$.

Using the rational that virtually all commercially available anticonvulsivants have shown efficacy in the treatment of migraine, this drug has recently been evaluated for this use. One first open study with 30 patients that had previously failed to at least two other agents has been levetiracetam added to their current preventive treatment. Fourteen (46.7\%) reported more than $50 \%$ reduction in their migraine frequency and intensity with 3 months of active therapy. Dosage was adjusted from 2,000 to $4,500 \mathrm{mg}$ per day in two or three doses. The authors concluded that levetiracetam could be an option in the treatment of refractory headaches $^{28}$.

A second study, with the same design, reported similar conclusions. The adverse event rates (no serious events were reported) was $16.1 \%{ }^{29}$.

\section{$G$-Zonisamide}

Zonisamide, an anticonvulsivant recently introduced in the US, has a unique combination of pharmacologic actions: it inhibits voltage-gated $\mathrm{Na}^{+}$ channels and also blocks T-type calcium channels ${ }^{30}$. Both of these mechanisms may play a role in headache and pain modulation, possibly via neuronal stabilization. An open study was performed on 27 patients, all with refractory headaches, that received zonisamide in addition to the preventive treatment. One hundred $\mathrm{mg}$ was given in the evening every third day and then increased every 2 weeks until a maximum dose of $600 \mathrm{mg}$ a day in 4 or 5 doses. Six (22.2\%) patients reported a $65 \%$ or better decrease in frequency of migraines; 8 (29.6\%) had from $25 \%$ to $50 \%$. Four $(14.8 \%)$ patients stopped due to side-effects ${ }^{30}$. A second study used from $10 \mathrm{mg}$ to 400 $\mathrm{mg}$, reported similar efficacy profiles. Paresthesias, fatigue, anxiety and weight loss were the most frequent adverse events reported ${ }^{31}$.

\section{3 - Miscellaneous}

\section{$H$ - Montelukast sodium}

Leukotrienes and other inflammatory mediators have been implicated in the inflammatory cascade believed to be associated with the pathophysiology of migraine ${ }^{32}$. The name "leukotriene" is derived both from the parent molecule, which was originally isolated from leukocytes, and from its three double-bond carbon backbone or triene structure. Both prostaglandins and leukotrienes are derived from the metabolism of arachidonic acid, with prostaglandins coming off the cyclooxygenase pathway and leukotrienes derived via the enzyme 5lipoxygenase. Both prostaglandins and leukotrienes mediate inflammatory responses $^{33}$.

Nonsteroidal anti-inflammatory agents have been used widely in the treatment of migraine. It is reasonable to think that medications that could antagonize leukotriene functions could be effective in migraine prevention. The clinical observation of a decrease in migraine frequency in patients with comorbid asthma taking montelukast, a specific D4 leukotriene receptor antagonist, lead to the first open study, by Sheftell et al. ${ }^{34}$, using montelukast sodium, 10 or $20 \mathrm{mg}$, in the prevention of migraine. In this study montelukast was extremely well tolerated, and no adverse events were reported by any of 
the patients. Fifty-three percent showed a reduction greater than $50 \%(\mathrm{P}<.025)$ in the frequency of severe attacks, with $41 \%$ showing a reduction greater than $60 \%$. Responders, including modest responders, rated the drug as excellent. The authors concluded that montelukast shows potential as an effective, well-tolerated prophylactic agent in migraine, double-blinded, placebo-controlled studies being necessary. Recently, a poster was presented at the 2001 International Headache Congress showing the efficacy and safety of this drug in children and adolescents ${ }^{35}$.

\section{I- Lisinopril}

Lisinopril (LSN) is a dicarboxylcontaining angiotensin converting enzyme (ACE) inhibitor proven efficient to treat hypertension and heart failure. It is structurally related to enalapril and it was the third ACE inhibitor approved for use in the United States. In vitro, LSN is slightly more potent than enalaprilat, an injectable ACE inhibitor, even though it is its lysine analog. After oral administration LSN is slowly, variably and incompletely (30\%) absorbed; peak plasma concentrations are achieved in about 7 hours. It is cleared as the intact compound by the kidney, and its half-life in plasma is about 12 hours. LSN does not accumulate in tissues. The suggested oral doses for hypertension ranges from 5 to $40 \mathrm{mg}$ daily (in single or divided doses), with $10 \mathrm{mg}$ daily being appropriate for the initiation of therapy ${ }^{36,37}$.

LSN was studied in a randomized, placebo-controlled, crossover trial ${ }^{38}$ for the prophylactic treatment of migraine. The study involved sixty patients, aged 19-59 years, that presented two to six migraine attacks in a 4-week run-in phase. In the 47 participants who completed the study, hours with headache, days with headache, days with migraine, and headache severity index were significantly reduced by
$20 \%, 17 \%, 21 \%$, and $20 \%$ respectively, with LSN compared with placebo. Days with migraine were fewer by at least $50 \%$ in 14 patients for active treatment versus PCB. LSN was well tolerated and side effects observed were those know to be associated with ACE inhibitors. Eight patients reported coughing (vs. 3 in placebo group, 3 patients of LSN group withdrew due to coughing), 3 reported fatigue (vs. 3 in placebo group), 7 presented dizziness (vs. 4 in PCB) and 3 reported tendency to faint (vs. 0 in PCB) (total side effects 24 LSN patients vs. 13 PCB patients, $\mathrm{p}=0.07$ ).

LSN has various pharmacological effects that may be relevant in migraine. In addition to blocking the conversion of angiotensin I to angiotensin II, it also alters the sympathetic activity, inhibits free radical activity, increases prostacyclin synthesis, and blocks the degradation of bradykinin, encephalin, and substance $\mathrm{P}^{39}$. Of particular relevance to LSN efficacy in migraine prevention, may be the recent finding that migraine without aura seems to be more common in people with the angiotensin converting enzyme DD gene, and the fact that migraineurs with this gene also have higher angiotensin converting enzyme activity and a higher frequency of attacks than other migraine sufferers ${ }^{39}$.

\section{$J$ - Botulinum toxin}

Botulinum toxin type A injections often reduce the pain associated with conditions such as cervical dystonia, achalasia, rectal fissures, and myofascial pain syndrome ${ }^{40}$. Some open-label, noncontrolled studies of botulinum toxin type A suggested benefits for patients with migraine. A recent double-blind study ${ }^{40}$, evaluating $25-\mathrm{U}$ and $75-\mathrm{U}$ doses showed that, compared with vehicle treatment, subjects in the 25-U botulinum toxin type A treatment group showed significantly fewer migraine attacks per month, a reduced maximum severity of migraines, a reduced number of days using acute migraine medications, and reduced incidence of migraine-associated vomiting. Both the $25-\mathrm{U}$ and $75-$ $\mathrm{U}$ botulinum toxin type $\mathrm{A}$ groups were significantly better than the vehicle group on subject global assessment. Botulinum toxin A treatment was well tolerated, with only the 75-U treatment group exhibiting a significantly higher rate of treatment-related adverse events than vehicle. They concluded that pericranial injection of botulinum toxin type $\mathrm{A}, 25 \mathrm{U}$, was found to be a safe treatment that significantly reduced migraine frequency, migraine severity, acute medication usage, and associated vomiting. It is symmetrically injected into glabellar, frontalis and temporalis muscles and eventually in other pericranial regions. The major side effect is mild ptosis that usually stays less than one week. Injections should be repeated every 3 months ${ }^{40}$. Clinical impression shows that some patients have a great response with this treatment, while other patients show practically absence or results.

\section{4 - Future Possibilities}

\section{$K$ - Calcitonin gene-related peptide antagonism.}

This kind of potentially promising migraine treatment is undergoing preclinical research. Calcitonin gene-related peptide (CGRP) is one of the most potent endogenous vasodilators known. This peptide is increased during migraine attacks and has been implicated in the pathogenesis of migraine headache. Its first small molecule selective CGRP antagonist has been synthesized: BIBN4096BS. In vitro, this compound is extremely potent at primate CGRP receptors exhibiting an affinity (Ki) for human CGRP receptors. In an in vivo model, BIBN4096BS in doses between 1 and 30 micrograms kg-1 (i.v.) inhibited the 
effects of CGRP, released by stimulation of the trigeminal ganglion, on facial blood flow in marmoset monkeys $^{41}$.

\section{CONCLUSIONS}

Analysis of preventive migraine therapies pose methodological issues $^{42}$. Many early studies done prior to the International Headache Society Classification ${ }^{43}$ used loose criteria to define migraine. Many preventives studies were poorly performed, did not provide adequate details of statistical methods or were reported only as abstracts, making proper analysis of the evidence difficult. Despite some of these drawbacks persisting until nowadays, we aimed to present an update of newer or less frequently used preventive migraine therapies, drugs that might reduce the burden and the costs of a disease that should be considered as a public health problem all around the world.
BIGAL ME e col. - Novas opções para o tratamento preventivo da migrânea: revisão com considerações fisiopatológicas. Rev. Hosp. Clín. Fac. Med. S. Paulo 57(6): 293-2982002.

INTRODUÇÃO: O tratamento farmacológico da migrânea pode ser dividido em agudo e preventivo. Crises de migrânea severas, de longa duração e incapacitante requerem profilaxia. Múltiplas linhas de pesquisa ao longo dos últimos 15 anos sedimentaram o conceito de que a migrânea é gerada a partir de um cérebro hiperexcitável. Variadas causas para essa hiperexcitabilidade têm sido sugeridas e incluem baixo nível de magnésio ce- rebral, anormalidades mitocondriais, disfunções relacionadas ao óxido nítrico e a existência de distúrbios nos canais de cálcio do tipo P/Q. O melhor conhecimento sobre a fisiopatologia da migrânea nos permite discutir novas opções terapêuticas.

OBJETIVOS: O objetivo do presente estudo é apresentar revisão baseada em evidências de novos agentes e outros que, embora disponíveis há mais tempo, não são freqüentemente utilizados, com considerações fisiopatológicas.

MÉTODOS/RESULTADOS: Serão revistos anticonvulsivantes com vários mecanismos de ação, como gabapentina, lamotrigina, topiramato, tiagabina, levetiracetam e zonisamida.
Serão revistos também produtos naturais, como riboflavina e magnésio, toxina botulínica do tipo A, um antagonista CGRP específico e uma nova opção para o tratamento da asma, o montelukast.

CONCLUSÕES: Objetivamos apresentar artigo de atualização em opções novas ou não freqüientemente utilizadas no tratamento preventivo da migrânea, drogas que podem reduzir o fardo e os custos de uma doença que deve ser considerada um problema de saúde pública em todo o mundo.

DESCRITORES: Migrânea. Tratamento preventivo. Tratamento profilático. Atualização.

\section{REFERENCES}

1. WELCH KM, D'ANDREA G, TEPLEY N et al. - The concept of migraine as a state of central neuronal hyperexcitability. Neurol Clin 1990; 8: 817-828.

2. WELCH KM, BARKLEY GL, TEPLEY N et al. - Central neurogenic mechanisms of migraine. Neurology 1993; 43: S21-S25.

3. LAURITZEN M - Pathophysiology of the migraine aura. The spreading depression theory. Brain 1994;117:199-210.

4. LANCE JW, LAMBERT GA, GOADSBY PJ et al. - Brainstem influences on the cephalic circulation: experimental data from cat and monkey of relevance to the mechanism of migraine. Headache 1983;23: 258-265.

5. WELCH KM, NAGESH V, AURORA SK et al. - Periaqueductal gray matter dysfunction in migraine: cause or the burden of illness? Headache 2001; 41: 629-637.
6. OPHOFF RA, TENWINDT GM \& VERGOUVE MN - Familial hemiplegic migraine and episodic ataxia type-2 are caused by mutations in the $\mathrm{Ca}^{2+}$ channel gene CACNLA4. Cell 1996; 87: 543-552.

7. WELCH KM \& RAMADAN NM - Mitochondria, magnesium and migraine. J Neurol Sci 1995; 134: 9-14.

8. MISHIMA K, TAKESHIMA T, SHIMOMURA T et al. - Platelet ionized magnesium, cyclic AMP, and cyclic GMP levels in migraine and tension-type headache. Headache 1997; 37: 561564.

9. ANTOZZI C, GARAVAGLiA B, MORA M et al. - Late-onset riboflavin-responsive myopathy with combined multiple acylcoenzime. A dehydrogenase and respiratory chain deficiency. Neurology 1994;44:2153-2158. 
10.ARTS WF, SCHOLTE HR, BOGGARD JM et al. - NADH-CoQ reductase deficience myopathy. Successful treatment with riboflavin. Lancet 1983;2:581-582.

11.SCHOENEN J, JACQUY J \& LENARTS M - Effectiveness of high-dose riboflavin in migraine prophylaxis. A randomized controlled trial. Neurology 1998;50:466-470.

12.RUDE RK \& SINGER FR - Magnesium deficiency and excess. Annu Rev Med 1981; 32: 245-259.

13.ALTURA BM \& ALTURA BT - Magnesium and vascular tone and reactivity. Blood Vessels 1978; 15:5-16.

14.PEIKERT A, WILIMZIG C \& KOHNE-VOLLAND R - Prophylaxis of migraine with oral magnesium: results from a prospective, multicenter, placebo-controlled and double-blind randomized study. Cephalalgia 1996;16:257-263.

15.PFAFFENRATH V, OSTREICH W \& HAASE W - Magnesium in the prophylaxis of migraine - a double-blind, placebocontrolled study. Cephalalgia 1996;16:436-440.

16.GOA KL \& SORKIN EM - Gabapentin: a review of its pharmacological properties and clinical potential in epilepsy. Drugs 1993;46:409-27.

17.GRAVES NM \& LEPPIK IE - Antiepileptic medications in development. Ann Pharmacother 1991;25:978-86.

18.MATHEW N, SAPER J \& MAGNUS-MILLER L - Efficacy and safety of gapapentin in migraine prophylaxis [abstract]. In: $17^{\text {th }}$ Annual Meeting of the American Pain Society, San Diego, Ca.

19.ROGAWSKI MA \& PORTER RJ. - Antiepileptic drugs: Pharmacological mechanisms and clinical efficacy with consideration of promising developmental stage compounds. Pharmacol Rev 1990;42:223-86.

20.EDMONDS HL Jr., JIANG YD, ZHANG PY et al. - Anticonvulsant activity of topiramate and phenytoin in a rat model of ischemiainduced epilepsy. Life Sci 1996; 59:127-131.

21.SHUAIB A, AHMED F, MURATOGLU M et al. - Topiramate in migraine prophylaxis. A pilot study. [abstract]. Cephalalgia 1999; 19:379-380.

22.POTTER DL, HART DE, CALDER CS et al. - A double-blind, randomized, placebo-controlled, parallel study to determine the efficacy of topamax (topiramate) in the prophylactic treatment of migraine [abstract]. Neurology 2000;52 (suppl 7):A15.

23.SUZDAK PD \& JANSEN JA - A review of the preclinical pharmacology of tiagabine: a potent and selective anticonvulsant GABA uptake inhibitor. Epilepsia 1995; 36:612-26.

24.ANON C - Tiagabine for epilepsy - Med Lett Drug Ther 1998; 40:45- 6 .

25.FREITAG FG, DIAMOND S \& SOLOMON GD - The prophylaxis of migraine with the GABA-agonist tiagabine: a clinical report. [abstract]. Headache 1999;19:354.

26.HARIA M \& BALFOUR JA - Levetiracetam. CNS Drugs 1997; 7:159-64.

27.UCB PHARMA INC. - Keppra ${ }^{\circledR}$ (levetiracetam) tablets prescribing information. Smyrna, GA; 1999 Dec 1.
28.KRUSZ JC - Levetiracetam as prophylaxis for resistant headaches. [abstract] Cephalalgia 2001,21:373.

29.DRAKE ME, GREATHOUSE NI, ARMENTBRIGHT AD et al. Levetiracetam for preventive treatment of migraine. [abstract]. Cephalalgia 2001,21:373

30.KRUSZ JC - Zonisamide in the treatment of headache disorders [abstract]. Cephalalgia 2001;21:374.

31.DRAKE ME, GREATHOUSE NI, ARMENTBRIGHT AD et al. Preventive treatment of migraine with zonisamide. [abstract]. Cephalalgia 2001;21:374

32.REISS TF, SORKNESS CA, STRICKER W et al. - Effects of montelukast (MK-0476), a potent cysteinyl leukotriene receptor antagonist, on bronchodilation in asthmatic subjects treated with and without inhaled corticosteroids. Thorax 1997; 52:45-8.

33.HAY DWP - Pharmacology of leukotriene receptor antagonists: more than inhibitors of bronchoconstriction. Chest 1997; 111(Suppl):35-45

34.SHEFTELL FD, RAPOPORT AM, WALKER B et al. - Leukotriene antagonists in the prophylaxis of migraine: a potential role for a new class of agents. Headache 1999;39:381.

35.PEARLMAN EM \& FISHER S - Preventive treatment for childhood and adolescent headache: role of once-daily montelukast sodium. [abstract]. Cephalalgia 2001;21:461.

36.KRYMCHANTOVSKI AV, BIGAL ME, MOREIRA PF - New and upcoming prophylactic agents for migraine. CNS drugs 2002;22:432-438

37.JACKSON EK \& GARRISON JC - Renin and Angiotensin. In HARDMAN JG, LIMBIRD LE, MOLINOFF PB et al. - Goodman and Gilman's The Pharmacological Basis of Therapeutics. $9^{\text {th }}$ ed. New York, McGraw-Hill, 1996. p. 733-758.

38.SKIDGEL RA \& ERDOS EG - The broad substrate specificity of human angiotensin converting enzyme. Clin Exp Hypertens 1987;9:243-259.

39.PATERNA S, DI PASQUALE P, D'ANGELO A et al. - Angiotensinconverting enzyme gene deletion polymorphism determines an increase in frequency of migraine attacks in patients suffering from migraine without aura. Eur Neurol 2000;43:133-136.

40.SILBERSTEIN SD, MATHEW N, SAPER J et al. - Migraine Clinical Research Group: Botulinum toxin type $A$ as a migraine preventive treatment. Headache 2000;40:445-450.

41.DOODS H, HALLERMAYER G, WU D et al. - Pharmacological profile of BIBN4096BS, the first selective small molecule CGRP antagonist. Br J Pharmacol 2000;129:420-423.

42.MCCROY DC, MATCHAR DB, ROSEMBERG JH et al. - Evidencebased guidelines for migraine headache: overview of migraine headache: overview of program description and methodology. Neurology [serial online]. Available at http:// www.neurology.org. Accessed Oct 2001.

43.INTERNATIONAL headache society committee on clinical trials in migraine - Guidelines for controlled trials of drugs in migraine: second edition. Cephalalgia 2000; 20: 765-786.

Received for publication on February 08, 2002.

See Editorial related to this article on page 249. 